\title{
UJI EFEKTIVITAS EKSTRAK ETANOL KACANG MERAH (Phaseolus vulgaris L.) TERHADAP PENURUNAN KADAR KOLESTEROL TOTAL PADA MENCIT PUTIH (Mus musculus) JANTAN
}

\section{THE EFFECTIVENESS TEST OF RED BEAN (Phaseolus vulgaris L.) ETHANOL EXTRACT TO DECREASE TOTAL CHOLESTEROL LEVEL IN MALE WHITE MICE}

\author{
Didin Ahidin*), Deni Firmansyah, Gina Khairunisah \\ Sekolah Tinggi Farmasi Muhammadiyah Cirebon \\ Jl. Cideng Indah No.03 Cirebon
}

Submitted : 17 September 2018 Reviewed : 14 Maret 2019 Accepted : 18 Maret 2019

\begin{abstract}
ABSTRAK
Kolesterol merupakan penyakit gangguan metabolik pada tubuh, salah satu herbal yang dapat menurunkan kadar kolesterol total adalah kacang merah. Kacang merah (Phaseolus vulgaris L.) merupakan tanaman yang diduga berpotensi sebagai penurun kadar kolesterol dalam darah karena memiliki kandungan flavonoida. Penelitian ini bertujuan untuk mengetahui efektivitas ekstrak etanol kacang merah (Phaseolus vulgaris L.) dalam menurunkan kadar kolesterol total pada dosis $14 \mathrm{mg} / 20 \mathrm{gBB}$ terhadap mencit putih (Mus musculus) jantan dengan bobot 20 gram yang diinduksi dengan makanan yang mengandung kolesterol. Pada penelitian ini ekstrak dibuat dengan metode maserasi dengan etanol $70 \%$ sebagai pelarut. Perlakuan dibagi dalam tiga kelompok, yaitu kelompok kontrol positif (Simvastatin dengan dosis $0,03 \mathrm{mg}$ ), kelompok kontrol negatif ( $\mathrm{Na} \mathrm{CMC} 0,5 \%$ ), kelompok perlakuan ekstrak etanol kacang merah dengan dosis $14 \mathrm{mg} / 20 \mathrm{gBB}$. Pengukuran kadar kolesterol dilakukan setiap dua hari sekali dan sebelumnya dipuasakan terlebih dahulu selama 8 jam. Pemeriksaan kadar kolesterol dengan metode biosensor amperometrik dengan menggunakan alat ukur Easy Touch. Data yang didapat dianalisis dengan uji statistik one way ANOVA dengan taraf kepercayaan 95\% kemudian dilanjutkan dengan uji Least Significant Different (LSD). Hasil penelitian menunjukan bahwa ekstrak etanol kacang merah pada dosis $14 \mathrm{mg} / 20 \mathrm{gBB}$ kurang efektif sebagai penurun kadar kolesterol darah mencit putuh (Mus musculus) jantan.
\end{abstract}

Kata Kunci : Kacang merah (Phaseolus vulgaris L.), mencit putih (Mus musculus) jantan, kolesterol

\begin{abstract}
Cholesterol is a metabolic disorder of the body, one of them herbs that can lower total cholesterol levels are red beans. Red beans (Phaseolus vulgaris L.) is a suspected plant potentially as lowering cholesterol levels in the blood as it has flavonoids content. This study aims to determine the effectiveness extract of red bean ethanol (Phaseolus vulgaris L.) in lowering levels total cholesterol at a dose of $14 \mathrm{mg} / 20 \mathrm{gBB}$ against white mice (Mus musculus) a male with a weight of 20 grams which is induced by the food contains cholesterol. In this study the extract is made by the method maceration with $70 \%$ ethanol as solvent. Treatment is divided into threegroup, that is positive control group (simvastatin with
\end{abstract}


dose $0,03 \mathrm{mg}$ ), negative control group ( $\mathrm{Na} \mathrm{CMC}$ ), ethanol extract treatment group red with a dose of $14 \mathrm{mg} / 20 \mathrm{gBB}$. Measurement of cholesterol levels is done every once every two days and previously authorized for 8 hours. Examination of cholesterol levels by amperometric biosensor method with use a measuring instrument Easy Touch. The data obtained were analyzed by the test One way ANOVA statistic with 95\% confidence level then continued with Least Significant Different (LSD) test. The results showed that red bean ethanol extract at a dose of $14 \mathrm{mg} / 20 \mathrm{gBB}$ is less effective as a lowering of blood cholesterol of male mice (Mus musculus).

Keywords : Red beans (Phaseolus vulgaris L.), white mice (Mus musculus) male, cholesterol.

\section{Penulis korespondensi:}

Didin Ahidin

Sekolah Tinggi Farmasi Muhammadiyah Cirebon

Jl. Cideng Indah No. 3 Cirebon

Email : didin.apt@gmail.com/No.HP : 087829977345

\section{PENDAHULUAN}

Kolesterol adalah konstituen membran plasma dan lipoprotein plasma. Kolesterol terdistribusi luas disemua sel tubuh, tetapi terutama dijaringan saraf. Kolesterol tinggi hanyalah sebuah faktor penyebab terjadinya penyakit jantung. Meskipun begitu, faktor tersebut adalah faktor yang sangat penting dalam proses terbentuknya aterosklerosis pada penyakit jantung (Nurrahmani dkk, 2015).

Pola makan merupakan salah satu faktor pemicu terjadinya tingginya kadar kolesterol LDL. Gorengan merupakan makanan yang sering ditemukan bahkan banyak sekali masyarakat yang gemar mengkonsumsi gorengan. Menurut Wahyu Suprapto pada buku (Pujiastuti dan Rosy, 2017) panganan gorengan memicu naiknya kolesterol. "Gorengan banyak mengandung asam lemak jenuh yang berasal dari minyak". Penelitian Rustika (2005) dari badan Penelitian dan Pengembangan Kesehatan di Jakarta Pusat menyatakan asam lemak jenuh di aneka gorengan cukup tinggi rata-rata mencapai $11,92 \%$.

Kacang merah (Phaseolus vulgaris L.) terkenal sebagai sumber protein nabati, disamping kaya akan protein biji kacang merah juga merupakan sumber karbohidrat, vitamin, dan mineral. Dibandingkan kacang-kacang lainnya, kacang merah memiliki kadar karbohidrat tinggi, kadar protein yang setara dengan kacang hijau, kadar lemak yang jauh lebih rendah dibanding kacang kedelai serta memiliki serat yang sama dengan kacang hijau (Astwan, 2009).

Pada penelitian Oriviyanti (2012), menyatakan bahwa jus kacang merah dapat meningkatkan kadar kolesterol LDL tetapi tidak signifikan $(p>0,05)$ dan terjadi peningkatan kadar kolesterol HDL secara signifikan $(\mathrm{p}<0,05)$ dan penurunan rasio kolesterol LDL/HDL tetapi tidak signifikan $(\mathrm{p}>0,05)$. Berdasarkan latar belakang di atas, penulis tertarik untuk menguji kacang merah yang berkhasiat sebagai tanaman obat yang dapat menurunkan kadar kolesterol total .

\section{METODE PENELITIAN}

\section{Alat dan Bahan}

Alat yang digunakan adalah Vaccum Rotary Evaporator (IKA ${ }^{\circledR R V} 10$ basic); Timbangan analitik (Ragwag 0-160g); Timbangan hewan mencit; Beker glass (Pyrex); Gelas ukur 100ml (Pyrex); Lumpang dan alu; Kertas saring; Water batt; Spuit needle feeding; Gunting bedah; Alat ukur Easy Touch; Srip kolesterol Easy Touch; Kandang mencit. Bahan yang digunakan 
adalah Kacang merah; Etanol 70\%; suspensi Natrium CMC 0,5\%; Simvastatin 10mg; Kuning telur ayam; Lemak kambing; Sukrosa $65 \%$.

\section{Hewan Uji}

Hewan uji yang digunakan adalah mencit putih (Mus musculus) jantan dengan bobot badan 20g. Jumlah mencit putih (Mus musculus) jantan yang dibutuhkan sebanyak 15 mencit, yang sebelumnya diadaptasikan terlebih dahulu selama tujuh hari.

\section{Jalannya Penelitian}

1. Ekstraksi Kacang Merah (Phaseolus vulgaris L.)

Sebanyak 400g kacang merah (Phaseolus vulgaris L.) dicuci bersih, ditiriskan setelah itu diblender hingga memperoleh kacang merah dengan luas penampang yang lebih besar. Dikeringkan pada oven dengan suhu $40^{\circ} \mathrm{C}$ selama 24 jam. Sebanyak $200 \mathrm{~g}$ simplisia kacang merah tersebut diekstraksi dengan metode maserasi dengan etanol $70 \%$ sebanyak $2000 \mathrm{ml}$. Hasil ekstraksi diuapkan dengan rotary evaporator selanjutnya dipekatkan di waterbath dengan suhu $\pm 45^{\circ} \mathrm{C}$ hingga diperoleh ekstrak kental.

2. Pembuatan suspensi ektrak etanol kacang merah $14 \%$

Sebanyak 1,4g ekstrak etanol kacang merah disuspensikan dengan Na CMC 0,5\% hingga $10 \mathrm{~mL}$. Dosis yang diberikan adalah $14 \mathrm{mg} / 20 \mathrm{gBB}$, dengan volume pemberian sebanyak $0,1 \mathrm{~mL}$.

\section{Pembuatan suspensi simvastatin}

Pembuatan suspensi simvastatin untuk mencit putih (Mus musculus) dengan dosis $0,03 \mathrm{mg} / 20 \mathrm{gBB}$ dibutuhkan satu tablet simvastatin, gerus dan ditimbang sebanyak $42 \mathrm{mg}$ kemudian disuspensikan dengan $\mathrm{Na}$ CMC $0,5 \%$ hingga $14 \mathrm{~mL}$. Volume larutan yang akan diberikan adalah $0,1 \mathrm{~mL}$.

\section{Pembuatan Makanan Induksi Kolesterol dan Lemak}

Komposisi makanan induksi kolesterol dan lemak terdiri dari campuran kuning telur $80 \%$, larutan sukrosa $65 \%$ sebanyak $15 \%$ dan lemak hewan 5\%. Dibuat dalam bentuk emulsi, semua bahan dicampurkan kemudian dikocok dengan kecepatan tinggi hingga homogen.

\section{Penyiapan dan Perlakuan Hewan Uji}

Penelitian akan dilakukan selama delapan hari lamanya dengan pengujian dilakukan setiap dua hari sekali. Dengan menggunakan mencit putih (Mus musculus) jantan. Hewan uji yang digunakan dalam penelitian ini sebanyak 15 mencit yaitu kontrol positif (diberi simvastatin dan pakan induksi kolesterol), kontrol negatif (diberi suspensi $\mathrm{Na}$ CMC 0,5\% dan pakan induksi kolesterol), kelompok perlakuan $(14 \mathrm{mg} / 20 \mathrm{gBB}$ dan pakan induksi kolesterol). Pemberian pakan tinggi kolesterol pada pukul pukul 07.00 dan 16.00 sebanyak $0,045 \mathrm{~g} / 20 \mathrm{~g}$, pemberian ekstrak etanol kacang merah (Phaseolus vulgaris L.) dosis $14 \mathrm{mg} / 20 \mathrm{gBB}$ pada pagi hari (jam 08.00) dan sore hari (jam 16.00).

6. Pengambilan sampel darah mencit putih jantan

Potong ujung ekor mencit, oleskan darah mencit pada strip kolesterol sampai darah mencukupi dan terdengar bunyi bip, maka angka digital akan bergerak, dalam waktu 1,5 menit akan terlihat berapa kadar kolesterol dalam darah mencit putih jantan.

\footnotetext{
ANALISIS DATA

Data kadar kolesterol, diolah dan dianalisis menggunakan uji statistik one way ANOVA lalu dilanjutkan menggunakan uji post hoc LSD (Least Significant Different) hasil penelitian dihasilkan dalam bentuk tabel dan grafik.
} 


\section{HASIL DAN PEMBAHASAN}

Jumlah ekstrak yang didapat dari proses ekstraksi etanol kacang merah (Phaseolus vulgaris L.) sebesar 35,97g dengan total rendemen ekstrak yaitu 17,98\%. Pada penelitian ini menggunakan tiga perlakuan yaitu kontrol positif dengan menggunakan simvastatin, kontrol negatif dengan menggunakan $\mathrm{Na} \mathrm{CMC} 0,5 \%$, perlakuan eksrak etanol kacang merah (Phaseolus vulgaris L.) dengan dosis $14 \mathrm{mg} / 20 \mathrm{gBB}$ mencit, masing-masing diberi pakan kolesterol untuk kontrol positif dan untuk kelompok perlakuan dengan dosis sebesar $0,045 \mathrm{~g} / 20 \mathrm{gBB}$. Pakan kolesterol merupakan makanan yang terdiri dari kuning telur 80 gram, larutan sukrosa $65 \%$ sebanyak 15 gram dan lemak kambing sebanyak 5 gram (Kurniawati, 2015). Hasil pengukuran kadar kolesterol total kelompok kontrol posotif, kontrol negatif dan kelompok uji dapat dilihat pada tabel IV, V dan VI.

Tabel IV. Kadar Kolesterol Total Kontrol Negatif (Na CMC)

\begin{tabular}{|c|c|c|c|c|c|c|}
\hline \multirow{2}{*}{ Mencit } & \multicolumn{3}{|c|}{ Kadar kolesterol dalam darah setiap 2 hari sekali } & \multirow{2}{*}{ Jumlah } & \multirow{2}{*}{$\begin{array}{c}\text { Rata- } \\
\text { rata }\end{array}$} \\
\cline { 2 - 5 } & $\begin{array}{c}\text { Hari ke- } \\
\mathbf{2}\end{array}$ & Hari ke-4 & Hari ke-6 & Hari ke-8 & & \\
\hline 1 & 140 & 132 & 135 & 247 & 654 & 163,50 \\
\hline 2 & 162 & 140 & 142 & 154 & 598 & 149,50 \\
\hline 3 & 143 & 135 & 150 & 145 & 573 & 143,25 \\
\hline 4 & 130 & 122 & 147 & 201 & 600 & 150,00 \\
\hline 5 & 148 & 137 & 135 & 143 & 563 & 140,75 \\
\hline Jumlah & 723 & 666 & 709 & 890 & 2988 & 747,00 \\
\hline $\begin{array}{c}\text { Rata- } \\
\text { rata }\end{array}$ & 144,6 & 133,2 & 141,8 & 178 & 597,6 & 149,40 \\
& $\pm 11,74$ & $\pm 6,91$ & $\pm 6,83$ & $\pm 45,22$ & $\pm 35,31$ & $\pm 8,82$ \\
\hline
\end{tabular}

Penelitian sebelumnya dilakukan oleh Oriviyanti (2012) tentang Perbedaan Pengaruh Yogurt Susu, Jus Kacang Merah dan Yogurt Kacang Merah Terhadap Kadar Kolesterol LDL dan Kolesterol HDL Serum Pada Tikus Dislipidemia, dalam penelitian tersebut jus kacang merah memiliki efek signifikan terhadap peningkatan kadar kolesterol HDL, untuk itu dimodifikasi menjadi ekstrak etanol kacang merah sebagai penurunan kadar kolesterol total.

Tabel V. Kadar Kolesterol Total Kontrol Positif (Simvastatin dosis 0,03mg)

\begin{tabular}{|c|c|c|c|c|c|c|}
\hline \multirow[t]{2}{*}{ Mencit } & \multicolumn{4}{|c|}{$\begin{array}{c}\text { Kadar kolesterol dalam darah setiap } 2 \text { hari sekali } \\
\text { selama } 8 \text { hari (mg/dL) }\end{array}$} & \multirow[t]{2}{*}{ Jumlah } & \multirow{2}{*}{$\begin{array}{c}\text { Rata- } \\
\text { rata }\end{array}$} \\
\hline & 2 & 4 & 6 & 8 & & \\
\hline 1 & 124 & 119 & 123 & 106 & 472 & 118 \\
\hline 2 & 153 & 125 & 143 & 108 & 529 & 132,25 \\
\hline 3 & 149 & 150 & 133 & 112 & 544 & 136 \\
\hline 4 & 133 & 115 & 100 & 100 & 448 & 112 \\
\hline 5 & 101 & 109 & 110 & 100 & 420 & 105 \\
\hline Jumlah & 660 & 618 & 609 & 526 & 2413 & 603,25 \\
\hline $\begin{array}{l}\text { Rata- } \\
\text { rata }\end{array}$ & $\begin{array}{l}132 \\
\pm 20,95\end{array}$ & $\begin{array}{l}123,6 \\
\pm 15,87\end{array}$ & $\begin{array}{l}121,8 \\
\pm 17,25\end{array}$ & $\begin{array}{l}105,2 \\
\pm 5,21\end{array}$ & $\begin{array}{l}482,6 \\
\pm 52,79\end{array}$ & $\begin{array}{l}120,65 \\
\pm 13,19\end{array}$ \\
\hline
\end{tabular}


Tabel VI. Kadar Kolesterol Total Ekstrak Etanol Kacang Merah (Phaseolus vulgaris $\mathrm{L}$.) dosis $14 \mathrm{mg} / 20 \mathrm{~g} B$

\begin{tabular}{|c|c|c|c|c|c|c|}
\hline \multirow{2}{*}{ Mencit } & \multicolumn{5}{|c|}{$\begin{array}{c}\text { Kadar kolesterol dalam darah setiap 2 hari } \\
\text { sekali selama 8 hari (mg/dL) }\end{array}$} & \multirow{2}{*}{$\begin{array}{c}\text { Rata- } \\
\text { rata }\end{array}$} \\
\cline { 2 - 5 } & $\mathbf{2}$ & $\mathbf{4}$ & $\mathbf{6}$ & $\mathbf{8}$ & & \\
\hline 1 & 142 & 126 & 129 & 137 & 534 & 133,5 \\
\hline 2 & 137 & 130 & 125 & 130 & 522 & 130,5 \\
\hline 3 & 149 & 153 & 138 & 150 & 590 & 147,5 \\
\hline 4 & 134 & 128 & 136 & 134 & 532 & 133 \\
\hline 5 & 141 & 135 & 128 & 134 & 538 & 134,5 \\
\hline Jumlah & 703 & 672 & 656 & 685 & 2716 & 679 \\
\hline Rata- & 140,6 & 134,4 & 131,2 & 137 & 543,2 & 135,8 \\
rata & $\pm 5,68$ & $\pm 10,92$ & $\pm 5,54$ & $\pm 7,68$ & $\pm 26,8$ & $\pm 6,70$ \\
\hline
\end{tabular}

Hasil grafik pengamatan dapat dilihat ini menunjukan ekstrak etanol kacang merah (Phaseolus vulgaris L.) memiliki efek untuk menurunkan kadar kolesterol total yang terlihat bahwa kelompok mencit yang diberi kontrol negatif ( $\mathrm{Na} \mathrm{CMC}$ ) berada paling bawah, karena pada kelompok kontrol ini tidak diberi obat yang berefek untuk menurunkan kadar kolesterol, sedangkan grafik ekstrak etanol kacang merah dosis $14 \mathrm{mg} / 20 \mathrm{~g}$ BB berada dibawah kontrol negatif (Na CMC) dan berada diatas kontrol positif (Simvastatin). Pada tabel IV menunjukan kelompok mencit kontrol negatif memiliki kadar kolesterol $149,4 \mathrm{mg} / \mathrm{dL}$, untuk kontrol positif menurunkan kadar kolesterol hingga 120,65mg/dL (Tabel.V) dan untuk kelompok perlakuan menurunkan kadar kolesterol hingga 135,8mg/dL (Tabel.VI), semua perlakuan memiliki kadar kolesterol yang tidak stabil dalam tiap pengujiannya dikarenakan mungkin metabolisme mencit yang berubah-ubah dan dikarenakan pakan standar yang selain memiliki protein yang tinggi pakan ini juga memiliki memiliki lemak yang tinggi sehingga menjadikan kadar kolesterol total pada mencit tersebut tinggi dan sebaiknya perlu adanya dosis pemberian makan standar untuk mencegah timbulnya ketidaksepadanan dalam memberikan makanan karena mencit memilki tingkat nafsu makan yang berbeda-beda yang akan membuat kadar kolesterolnya tidak stabil.

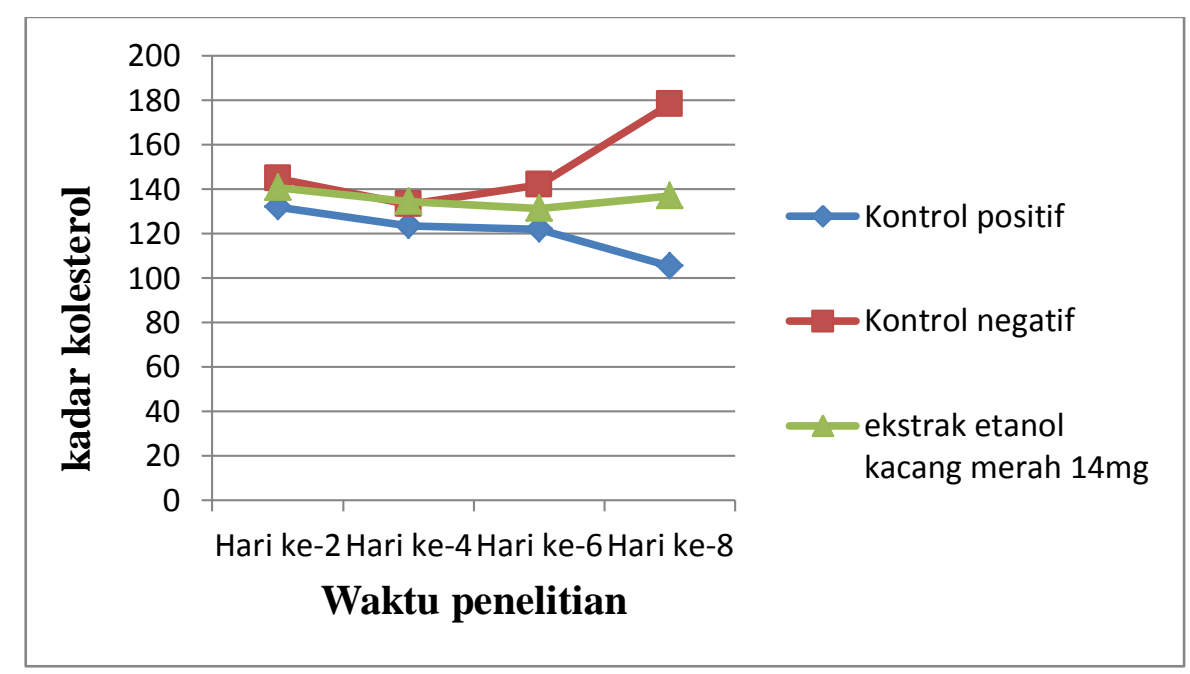

\section{Gambar I. Grafik perbandingan berbagai kontrol dan berbagai dosis ekstrak etanol kacang merah (Phaseolus vulgaris L.).}

Ekstrak etanol kacang merah yang dibuat sebaiknya sebelum penelitian dilakukan penapisan fitokimia kualitatif terlebih dahulu agar dapat mengetahui bahwa ekstrak tersebut 
mengandung flavonoida dan dilanjutkan penetapan kadar flavonoida total untuk memudahkan dalam penentuan dosis yang akan diberikan untuk penelitian.

Hewan yang akan diuji sebaiknya sebelum penelitian diberi pakan tinggi kolesterol terlebih dahulu selama \pm 3 hari setelah itu lakukan pengecekan kadar kolesterol totalnya tujuannya agar dapat melihat dan mengelompokan beberapa mencit putih (Mus musculus) jantan yang memiliki kadar kolesterol tinggi, agar penelitian yang dilakukan dapat terlihat jelas penurunan kadar kolesterol totalnya.

Dari data statistika terlihat bahwa rata-rata kadar kolesterol terdistribusi normal dan homogen, maka dilakukan uji statistik analisis ANOVA one way lalu dilanjutkan dengan uji LSD yang bertujuan untuk mengetahui signifikansi dari masing-masing kelompok. Dari hasil uji LSD kontrol negatif dengan ekstrak etanol kacang merah (Phaseolus vulgaris L.) dosis $14 \mathrm{mg} / 20 \mathrm{~g}$ BB $\mathrm{p}>0,05(0,052)$ artinya ekstrak etanol kacang merah (Phaseolus vulgaris L.) dosis $14 \mathrm{mg} / 20 \mathrm{~g}$ BB tidak mempunyai perbandingan efek yang signifikan dibandingkan dengan kontrol negatif. Dengan demikian, pada penelitian ini kandungan ekstrak etanol kacang merah (Phaseolus vulgaris L.) kurang efektif sebagai penurun kadar kolesterol darah mencit putih (Mus musculus).

\section{KESIMPULAN}

1. Ekstrak etanol kacang merah (Phaseolus vulgaris L.) pada dosis $14 \mathrm{mg} / 20 \mathrm{~g}$ BB mencit yang diuji dengan statistik one way ANOVA kurang efektif terhadap penurunan kadar kolesterol total darah mencit putih (Mus musculus) jantan.

2. Ekstrak etanol kacang merah (Phaseolus vulgaris L.) dosis $14 \mathrm{mg} / 20 \mathrm{~g}$ BB mencit memiliki efek penurunan kadar kolesterol lebih rendah dibandingkan dengan simvastatin $0,03 \mathrm{mg} / 20 \mathrm{~g}$ BB pada mencit putih (Mus musculus) jantan.

\section{DAFTAR PUSTAKA}

Astwan, M. 2009. Sehat Dengan HidanganKkacang dan Biji-bijian. Penebar swadya: Depok

Cahyono, B. 2003. Kacang Buncis. Kanisius: Yogyakarta

Diana, R. 2009. Pengaruh Vaksinasi Kultur Klebsiella Pneumonia Hasil Inaktivasi Pemanasan dan Radiasi Sinar Gamma Terhadap Kondisi Fisik serta Profil Serum Darah Mencit. Skripsi Universitas Islam Negeri Syarif Hidayatullah: Jakarta

Djamil, Ratna dan Anelia, Tria. 2009. Penapisan Fitokimia, uji BSLT dan Uni Antioksidan Ekstrak Metanol beberapa spesies Papilionaceae. Jurnal ilmu kefarmasian. Vol.7: 6571

Endarini, L.H . 2016. Farmakognosi dan Fitokimia. Jakarta. 145-148

Harmita dan Maksumradji. 2008. Buku Ajar Analisis Hayati, Edisi III. Buku kedokteran EGC: Jakarta

Gani, N., L.I, Momuat, dan M.M, Pitoi. 2013. Profil Lipida Serum Tikus Wistar yang Hiperkolesterolemia pada Pemberian Gedi Merah Abelmoschus manihot L. J. MIPA UNSRAT.: 44-49.

Harti, S. 2014. Biokimia Kesehatan. Nuha Medika: Yogyakarta

Junaidi, I. 2009. Pedoman Praktis Obat Indonesia. PT Bhuana Ilmu Populer: Jakarta. 199210

Khuswardani, S., Ignas (Ed). 2016. Manfaat dan Khasiat Kacang. Andi Offset: Yogyakarta. 25-26

Kurniawati, A. 2015. Uji Efek antihiperlipidemia Ekstrak etanol Buah Parijoto Terhadap Kolesterol Total, Trigliserida dan VLDL Pada Tikus Putih Jantan. Skripsi. Program pendidikan sarjana Farmasi UIN syarif Hidayatullah Jakarta

Manganti, I. 2017. Tanaman Obat untuk Menurunkan Kolesterol dan Mengobati asam Urat. 1th ed. Araska: Yogyakarta. 3-4 
Mokhtar, U. 2008. Pengaruh Pemberian Jus Tomat Terhadap Kadar Kolesterol LDL Tikus Putih. Skripsi. Program Pendidikan sarjana Kedokteran Universitas Sebelas Maret.

Murray, R.K., Granner, D.K., Mayes, P.A., Rodwell, V.W. Lehninger, A.L. 2012. Harper's Ilustrated Biochemistry, 26th Ed., Lange medical Books/Mc.Graw-Hill

Nurrahmani, U dan Kurniadi, H., Qoni (Ed). 2015. STOP Gejala Penyakit Jantung Koroner, Kolesterol Tinggi, Diabetes Melitus, Hipertensi. Istana Media: Yogyakarta

Oriviyanti, G. 2012. Perbedaan Pengaruh Yogurt Susu, Jus Kacang Merah dan Yogurt Kacang Merah Terhadap Kadar Kolesterol LDL dan Kolesterol HDL Serum Pada Tikus Dislipidemia. Skripsi. Program Pendidikan Sarjana Kedokteran Universitas Diponegoro. 37-38

Pujiastuti, E., Rosy (Ed). 2017. Herbal Penakluk Kolesterol. PT Trubus Swadaya: Depok.3-4

Purwanto, B., Mahadewa (Ed). 2016. Obat Herbal Andalan Keluarga. FlashBooks: Yogyakarta

Rusilanti dan Kusharto, C, M. 2007. Sehat dengan makanan berserat. PT Agromedia Pustaka: Jakarta

Glory, L. 2016. Perubahan kadar kolesterol total dan trigliserida pada kelinci New Zealand white yang diberi ekstrak beras hitam (Oryza sativa L.). Jurnal e-Biomedik (eBm). Vol.4: 1-6

Sumia. 2015. Efek Diuretik Ekstrak Etanol Daun Bit Terhadap Mencit Putih Jantan. Karya Tulis Ilmiah. Program DIII Farmasi Akademi Farmasi Muhammadiyah Cirebon.

Wijayakusuma, H. 2005. Atasi Kanker Dengan Tanaman Obat. Puspa Swara: Jakarta 
